\title{
\begin{tabular}{c|c|}
\hline Jurnal Abdimas Saintika & $\begin{array}{l}\text { e-ISSN : 2715-4424 } \\
\text { p-ISSN :2746-797X }\end{array}$ \\
\hline Volume 3 Nomor $1 \mid$ https://jurnal.syedzasaintika.ac.id
\end{tabular}
}

\section{IMPLEMENTASI SISTEM INFORMASI KESEHATAN ANAK SEKOLAH DI SD N 22 PADANG TIMUR}

\author{
Chamy Rahmatiqa ${ }^{1^{*}}$, Alfita Dewi ${ }^{2}$, Vitraturrahmah ${ }^{3}$ \\ 1,2,3Program Studi Sarjana Terapan Manajemen Informasi Kesehatan, \\ Stikes Syedza Saintika \\ *Email : chamyrahmatiqa@gmail.com
}

\begin{abstract}
ABSTRAK
Jumlah populasi anak sekolah yaitu $28 \%$ dari total penduduk Indonesia yang tentunya jumlah yang sangat besar sehingga memberikan dampak positif bagi pembangunan . Pemantauan kesehatan usia sekolah belum berjalan dengan baik, kendalanya adalah proses rekapitulasi secara manual membutuhkan waktu analisis yang lebih lama Kegiatan ini dilaksanakan di SD N 22 Padang Timur. Sasaran kegiatan adalah dokter kecil. Kegiatan pengabdian kepada masyarakat yang dilakukan Kegiatan pengabdian kepada masyarakat yang dilakukan adalah pengukuran pengetahuan dokter kecil tentang pencatatan dan pengelolaan riwayat kesehatan anak usia sekolah. Sebelum diadakan penyuluhan terlebih dahulu diberikan pretest dan setelah penyuluhan diadakan posttest. Hasil adalah ditemukannya dari 10 dokter kecil sebanyak $60 \%$ (6 orang) memiliki tidak pengetahuan tentang ASI Eksklusif, dan hanya $40 \%$ (4 orang) berpengetahuan dengan baik. Hasil dari pelaksanaan penyuluhan terlihat ada peningkatan pengetahuan, dimana sebanyak $80 \%$ ( 8 orang) berpengetahuan baik. Simpulan dalam pengabdian masyarakat adalah adanya peningkatan pengetahuan ibu setelah pemberian penyuluhan kesehatan tentang ASI Eksklusif dari 40\% menjadi 80\%. Diharapkan Kepada pihak Puskesmas Air Tawar diharapkan melakukan penyuluhan tentang UKS minimal 3 bulan sekali dan menyediakan angggaran khusus untuk program pencapaian UKS ini di Wilayah Kerja Puskesmas Air Tawar Timur padang.
\end{abstract}

Kata Kunci: Dokter Kecil, sistem informasi kesehatan

\section{ABSTRACT}

The total population of school children is $28 \%$ of the total population of Indonesia are of course a very large number so that gives positive impact for the development. Monitoring the health of school age has not been running well, the obstacle is the process of recapitulation manually takes time analysis which is the duration of the Activity is implemented in SD N 22 Padang Timur. The target of the event is the little doctor. Community service activities are performed community service Activities are performed is the measurement of the doctor's knowledge of recording and the management of the medical history of the children of school age. Before education was held first given a pretest and after the counseling held posttest. The result is the discovery of 10 small doctor as much as 60\% (6 people) have no knowledge about Exclusive BREASTFEEDING, and only $40 \%$ (4 people) knowledgeable with good. The results of the implementation of the extension seen an increase in knowledge, where as much as $80 \%(8$ people) good knowledgeable. Conclusion in community service is to increase the knowledge of the mother after the provision of health education about breast MILK Exclusive from $40 \%$ to 80\%. Expected To the health center Fresh Water is expected to perform the extension of the 


\section{Jurnal Abdimas Saintika}

Volume 3 Nomor $1 \mid$ https://jurnal.syedzasaintika.ac.id

UKS minimum of 3 months and provides budgetary special program for the achievement of the INFIRMARY is in the Working Area of Puskesmas Freshwater East padang..

Keywords: Small Doctor, health information systems

\section{PENDAHULUAN}

Anak usia sekolah berumur 6-21 tahun merupakan kelompok rentan terhadap permsalahan kesehatan. Jumlah populasi anak sekolah yaitu $28 \%$ dari total penduduk Indonesia yang tentunya jumlah yang sangat besar sehingga memberikan dampak positif bagi pembangunan (Yanti, Fridalni, \& Neta, 2011). Masa usia ini dalam pertumbuhan akhir fisik yang sangat cepat dan tidak seimbang perkembangan mental dan sosial. Hal ini akan mempengaruhi pada perilaku anak sekolah, pendidikan formal di sekolah dan pendidikan informal di keluarha atau lingkungan sangat berperan dan paling dominan membentuk perilaku anak (Rahmatiqa, Sulrieni, \& Sary, 2020).

Anak usia sekolah dikelompokkan berdasarkan batas usia: prasekolah, usia sekolah, remaja, awal usia dewasa. Anak usia sekolah adalah anak yang sedang menekuni proses pendidikan mulai pada tingkat pra sekolah (TK), sekolah dasar hingga sekolah menengah pertama dan menengah atas (Saputro, Budiarti, \& Herawati, 2016). Masalah kesehatan yang terjadi pada anak usia sekolah sangat kompleks dan bervariasi disetiap tingkatan umurnya. Saat ini, kesehatan anak usia sekolah pada tingkat sekolah dasar sebagian besar terkait pada perilaku hidup bersih dan sehat perorangan. Sementaran, remaja (10-19 tahun) lebih terkkait dengan perilaku seksual dan merokok (Prasetyo, 2014).

Anak usia sekolah merupakan sasaran pembinaan kesehatan yang sangat strategis untuk mempersiapkan generasi penerus bangsa yang sehat, produktif, dan berkualitas sehingga mampu bersaing secara global (Maulana, Masturoh, \& Lena, 2018). Pembinaan kesehatan bertujuan untuk mengurangi potensi komplikasi dan permasalahan kesehatan anak usia sekolah sangat perlu dilakukan deteksi dini gangguan kesehatan agar tidak berkembang menjadi masalah cukup berarti dikemudian hari. Deteksi dini dapat dilakukan dengan meningkatkan pergatuan yang lebih besar terhadap usia sekolah (Masturoh, Maulana, \& Suryani, 2019).

Pemantauan kesehatan usia sekolah pemerintah melalui Puskesmas melakukan kegiatan penjaringan anak sekolah. Hasil kegiatan tersebut dilaporkan dalam bentuk laporan kegiatan hasil penjaringan dan laporan bulanan. Kegiatan ini yang dinamakan kegiatan Usaha Kesehatan Sekolah (UKS) (Rahmawati \& Soetopo, 2015). UKS sangat penting dilaksanakan guna menekan berbagai permasalahan kesehatan dan perilaku beresiko kelompok anak usia sekolah. Dalam pelaksanaan UKS sangat diperlukan dukungan data dan informasi guna membantu penyelenggara program sehingga tujuan program tersebut terjalankan dengan baik (Prasetyo, 2014). Sistem informasi bertujuan mengumpulkan, mengolah, dan menganalisis informasi serta menyediakan umpan balik untuk mendukung program tersebut (Nurhayu, Shaluhiyah, \& Indraswari, 2018).

Sistem pencatatam dam pelaporan hasil kegiatan UKS masih dilakukan secara manual. Rekapitulasi data untuk dijadikan laporan dari Puskesmas sampai ke Dinas Kesehatan Kota Padang dilakukan dengan memasukkan beberapa variabel data yang sama ke formulir pencatatan yang berbeda setiap lininya. Proses rekapitulasi data dari Puskesmas sampai ke Dinas Kesehatan Kota Padang 


\section{Jurnal Abdimas Saintika}

Volume 3 Nomor 1 | https://jurnal.syedzasaintika.ac.id

dilakukan secara berulang dengan menggunakan berbagai format pencatatan yang berbeda di setiap lininya. Proses tersebut berdampak pada konsistensi data, dimana seringkali ditemukan perbedaan rekapan data (Fadly \& Fadilla, 2020). Selain itu proses rekapitulasi secara manual membutuhkan waktu analisis yang lebih lama sehingga berdampak pada keterlambatan pelaporan dan penyampaian informasi kepada pihak manajerial. Hal tersebut otomatis juga akan berdampak pada penangganan berbagai permasalahan kesehatan anak usia sekolah yang terjadi karena ketersediaan data dan informasi yang akurat sebagai dasar pengambilan keputusan (Kapti, Ahsan, \& Istiqomah, 2013).

Tujuan dalam pengabdian masyarakat ini adalah melaksanakan upaya pembinaan terhadap dokter kecil dan guru UKS di SD Negeri 22 Padang Timur mengenai pencatatan dan pengelolaan riwayat kesehatan anak usia sekolah dan memberikan KMS manual dan raport Kesehatan anak usia sekolah dalam rangka memantau perkembangan kesehatan siswa-siswi SD tersebut.

\section{METODE}

Kegiatan ini dilaksanakan di SD Negeri 22 Padang Timur. Sasaran kegiatan adalah dokter kecil di SD Negeri 22 Padang Timur. Kegiatan pengabdian kepada masyarakat yang dilakukan adalah pengukuran pengetahuan dokter kecil tentang pencatatan dan pengelolaan riwayat kesehatan anak usia sekolah, dilanjutkan dengan pemberian pencatatan dan pengelolaan riwayat kesehatan anak usia sekolah dan KMS manual serta raport Kesehatan anak usia. Sebelum diadakan penyuluhan terlebih dahulu diberikan pretest dan setelah penyuluhan diadakan posttest. Kegiatan ini dilakukan pada tanggal 1 Februari 2021.

\section{HASIL DAN PEMBAHASAN}

Hasil dari kegiatan pengabdian kepada masyarakat yang telah dilakukan ada 10 dokter kecil. Pada dokter kecil $60 \% \quad(6$ orang) memiliki tidak pengetahuan tentang pencatatan dan pengelolaan riwayat kesehatan anak usia sekolah, dan hanya $40 \%$ (4 orang) berpengetahuan dengan baik. Hasil dari pelaksanaan penyuluhan terlihat ada peningkatan pengetahuan, dimana sebanyak $80 \%$ ( 8 orang) berpengetahuan baik. Hasil pretest menunjukkan rata rata pengetahuan sasaran sebelum penyuluhan adalah 6,4 dan posttest adalah 8.9.

Secara umum masalah yang dihadapi adalah banyaknya dokter kecil tidak dijalankan dengan baik. Selain itu, permasalahaannya adalah belum adanya pelatihan UKS kepada guru bimbingan UKS karena terkait dengan covid-19. Dilihat dari sudut sarana dan prasarana, banyaknya sekolah sudah mempunyai ruangan UKS tetapi tidak selayaknya digunakan untuk ruangan UKS.

Permasalahan lainnya yang ditemukan adalah adanya beberapa formulir pencatatan kesehatan yang berbeda tapi satu tema sama-sama tentang pencatatan kesehatan yang harus diisi dan dilaporkan ke Dinas Kesehatan. Hal ini menjadi tambahan beban tersendiri bagi para petugas. Dengan adanya buku rapor kesehatan anak sekolah sebetulnya sudah cukup memadai dan komprehensif, hanya buku tersebut belum tersosialisasikan ke semua sekolah. Kelemahan laporan hasil pencatatan penjaringan belum dilakukan secara online sehingga hasilnya tidak dapat langsung diketahui oleh pemangku kebijakan yaitu Dinas Kesehatan.

\section{SIMPULAN}

Simpulan dalam pengabdian masyarakat adalah adanya peningkatan pengetahuan dokter kecil tentang 


\section{Jurnal Abdimas Saintika}

encatatan dan pengelolaan riwayat kesehatan anak usia sekolah $40 \%$ menjadi $80 \%$. Diharapkan Kepada pihak Puskesmas Air Tawar Timur diharapkan melakukan penyuluhan tentang UKS minimal 3 bulan sekali dan menyediakan Fadly, F., \& Fadilla, S. P. (2020). Rancangan Basis Data Sistem Informasi Usaha Kesehatan Sekolah. Techno Xplore: Jurnal Ilmu Komputer dan Teknologi Informasi, 5(2), 49-55.

Kapti, R. E., Ahsan, A., \& Istiqomah, A. (2013). Pengaruh Bermain Dengan Mewarnai Terhadap Penurunan Skor Perilaku Maladaptif Anak Usia Prasekolah (3-5 Tahun) Yang Mengalami Hospitalisasi Di Rumah Sakit Kabupaten Kediri. Jurnal Ilmu Keperawatan, 1(2), 169-175.

Masturoh, I., Maulana, H. D., \& Suryani, D. L. (2019). IMPLEMENTASI SISTEM INFORMASI KESEHATAN ANAK SEKOLAH DI WILAYAH KOTA TASIKMALAYA TAHUN 2018. Edukasi Masyarakat Sehat Sejahtera (EMaSS): Jurnal Pengabdian kepada Masyarakat, 1(2), 164167.

Maulana, H. D., Masturoh, I., \& Lena, D. (2018). SOSIALISASI PENCATATAN RIWAYAT KESEHATAN PRIBADI (ANAK USIA SEKOLAH) ELECTRONIC PERSONAL HEALTH RECORD (e-PHR) DI WILAYAH

DINAS KESEHATAN KOTA TASIKMALAYA TAHUN 2017. Prosiding Pengabmas, 1(1), 194201.

Nurhayu, M. A., Shaluhiyah, Z., \& Indraswari, R. (2018). Pelaksanaan trias usaha kesehatan angggaran khusus untuk program pencapaian UKS ini di Wilayah Kerja Puskesmas Air Tawar Timur padang.

\section{DAFTAR PUSTAKA}

sekolah pada tingkat sekolah dasar di wilayah Kecamatan Tembalang Kota Semarang. Jurnal Kesehatan Masyarakat (EJournal), 6(1), 770-779.

Prasetyo, Y. B. (2014). Pelaksanaan Program Usaha Kesehatan Sekolah Dalam Upaya Meningkatkan Derajat Kesehatan Pada Anak Usia Sekolah Dasar di Lombok Timur. Jurnal Kedokteran Yarsi, 22(2), 102-113. Rahmatiqa, C., Sulrieni, I. N., \& Sary, A. N. (2020). Kelengkapan Berkas Rekam Medis dan Klaim BPJS di RSUD M. Zein Painan. Jurnal Kesehatan Medika Saintika, 11(1), 11-15.

Rahmawati, E. I., \& Soetopo, H. (2015). Manajemen Usaha Kesehatan Sekolah. Universitas Negeri Malang.

Saputro, W., Budiarti, L. Y., \& Herawati, H. (2016). PERILAKU HIDUP BERSIH DAN SEHAT (PHBS) DENGAN KEJADIAN DIARE PADA ANAK SEKOLAH DASAR (SD). Dunia Keperawatan, 1(1), 40-47.

Yanti, E., Fridalni, N., \& Neta, M. (2011). Hubungan Stimulasi Terhadap Perkembangan Motorik Halus Anak Prasekolah Usia (3-5 Tahun) Di PAUD Al-Mubaraqah Ampang Kecamatan Kuranji Tahun 2011. Retrieved Juni, 2, 2016. 